Article

\title{
Potential Utilization of a Polysaccharide from the Marine Algae Gayralia oxysperma, as an Antivenom for Viperidae Snakebites
}

\author{
Ana Cláudia Rodrigues da Silva ${ }^{1}$, Maria Eugenia Rabello Duarte ${ }^{2, *}$, Miguel Daniel Noseda ${ }^{2}$, \\ Luciana Garcia Ferreira ${ }^{2}$, Juliana Emanuela Fogari Cassolato ${ }^{2}$, Eladio Flores Sanchez ${ }^{3}$ and \\ Andre Lopes Fuly ${ }^{1, *(1)}$ \\ 1 Department of Molecular and Cellular Biology, Federal Fluminense University, Niterói, \\ Rio de Janeiro 24020-141, Brazil; anacrs1@yahoo.com.br \\ 2 Department of Biochemistry and Molecular Biology, Federal University of Paraná, Curitiba, \\ Paraná 81531-980, Brazil; mdn@ufpr.br (M.D.N.); lugarciaferreira@gmail.com (L.G.F.); \\ jcassolato@yahoo.com.br (J.E.F.C.) \\ 3 Laboratory of Biochemistry of Proteins from Animal Venoms, Research and Development Center, Ezequiel \\ Dias Foundation, Belo Horizonte, Minas Gerais 30510-010, Brazil; eladiooswaldo@gmail.com \\ * Correspondence: nosedaeu@ufpr.br (M.E.R.D.); andrefuly@id.uff.br (A.L.F.); \\ Tel.: +55-41-3361-1663 (M.E.R.D.); +55-21-2629-2294 (A.L.F.)
}

Received: 20 August 2018; Accepted: 25 October 2018; Published: 27 October 2018

check for updates

\begin{abstract}
Worldwide, snakebites have serious implications for human health. The administration of antivenom is the official treatment used to reverse the toxic activities of envenomation. However, this therapy is not efficient to treat the local effects, leading to the amputation or deformity of affected limbs. As such, alternative treatments are needed. Here, we analyze the ability of a polysaccharide from the green marine alga Gayralia oxysperma (Go3) to inhibit the effects of venom from Bothrops jararaca and Lachesis muta. B. jararaca or L. muta venoms were incubated together with sulfated heterorhamnans from Go3, and the in vitro (coagulation, proteolytic, and hemolytic) and in vivo (hemorrhagic, myotoxic, edematogenic, and lethal) activities of venoms were assessed. Additionally, Go3 was injected before and after the injection of venoms, and the toxic activities were further tested. When incubated with the venoms, Go3 inhibited all activities, though results varied with different potencies. Moreover, Go3 neutralized hemorrhagic, myotoxic, and edematogenic activities when injected before or after injection with B. jararaca and L. muta venom. Go3 also blocked the coagulation of plasma in mice caused by the venoms in an ex vivo test. Therefore, Go3 has the potential to be used as antivenom for B. jararaca and L. muta bites, notably exhibiting higher efficacy on L. muta venom.
\end{abstract}

Keywords: snake venom; Bothrops jararaca; Lachesis muta; green marine alga; Gayralia oxysperma; polysaccharide; neutralization; antivenom

\section{Introduction}

Snakebites represent a global public health problem. According to the World Health Organization (WHO), snakebites are a neglected tropical disease that affects 5.5 million people annually, resulting in approximately 400,000 amputations and 120,000 deaths. However, epidemiological studies are inadequate and unreliable, resulting in such figures being underestimated [1-3]. In Brazil, most snakebites are caused by the family Viperidae (vipers), which includes the genera Crotalus, Bothrops, and Lachesis. The latter two genera are responsible for the highest incidence (90\%) and lethality (1\%), respectively [4]. Snake venoms are composed of a mixture of active and non-active enzymes that produce toxic and harmful local (pain, inflammation, tissue necrosis, and hemorrhage) and systemic 
effects (hemorrhage, blood coagulation disorders, renal, cardiac or pulmonary failures, and death) in victims [4]. As a consequence of these effects, victims may die or survive with permanent physical damage. Thus, the economic impact of snakebites on communities can be considerable, mainly because victims are, in general, the most economically productive [5].

To date, apart from supportive care, the official and effective treatment for envenomation by snakebite is the intravenous administration of antivenom (immunoglobulins) [6]. In most registered cases, antivenom efficiently neutralizes the systemic effects of venoms, preventing death. However, some factors may hinder the complete success of antivenom in inhibiting venom toxicity, such as delays in administration, inappropriate dosages, side effects (mild fever to anaphylactic reactions), and in rare situations, the incorrect choice of antivenom [7,8]. Moreover, some antivenom poorly neutralizes the local effects of venom, which may lead to deformities or amputations of affected limbs [9]. Therefore, the search for alternative or complementary treatments capable of minimizing or counteracting the toxic effects of snakebites without side effects is relevant, and deserves attention. In fact, there is a need to develop more effective antivenom and therapeutics to snakebites. Research of small molecule inhibitors and peptides, as well as recombinant antivenoms, has increased [10-12]. Natural products, primarily from plants, have been extensively investigated as antivenoms, and some have been used regularly as traditional medicine by indigenous communities for such purposes [13]. Although the marine environment has more living organisms than the terrestrial, it remains poorly investigated regarding the discovery of biologically-active molecules with antivenom effects. Among such organisms, seaweeds should be considered, since they produce a great diversity of molecules with pharmacological and biological effects, some of which are of medical and industry interest [14].

Among marine organisms, green algae have been extensively investigated due to their bioactive compounds, widespread distribution, and large biomass production. Sulfated polysaccharides obtained from the genera Monostroma, Ulva, and Enteromorpha are known to display a variety of biological activities, such as antiviral [15-19], antioxidant [20], antihyperlipidemic [21,22], and plant resistance-inducers [23]. Monostromatic marine algae belonging to the genus Gayralia (Chlorophyta) comprises two species: G. oxysperma and G. brasiliensis [24]. Some species related to the Gayralia genus, such as the monostromatic Monostroma sp., are cultivated and used in the food and cosmetics industries [25]. These species synthesize sulfated rhamnans that are principally constituted of 2-, 3-, or 4-linked rhamnosyl units. The sulfate groups are principally positioned on C-2, C-3, and C-4, or on both C-3 and C-4 [23-26]. Crude extract obtained from the green seaweed Gayralia oxysperma is composed of sulfated heterorhamnans [26]. G. oxysperma (Go3) was obtained by aqueous extraction at $80{ }^{\circ} \mathrm{C}$ (13.8 wt \% yield, based on dried and milled seaweed), and presented a composition of $49.6 \%$ total carbohydrates and $17.0 \%$ uronic acids. Go3 is highly sulfated (25.3\%), and presents rhamnose as the major monosaccharide, as well as minor amounts of xylose, glucose, galactose, glucuronic acid, galacturonic acid, and very low percentages of arabinose and mannose (59.0, 9.0, 10, 6, 11, 3, 1, and $1 \mathrm{~mol} \%$, respectively). Chemical and spectroscopic analyses performed with the major sulfated heterorhamnan constituent of Go3 (70\%) demonstrated that 3-linked units are sulfated on C-2, C-4, disulfated, and unsulfated in a molar ratio of 1:077:038:0.46, respectively. The 2-linked rhamnosyl units are principally sulfated on C-4, sulfated on both C-3 and C-4, and unsulfated (1:0.37:0.50, respectively). Furthermore, glucuronic 2-sulfate and galacturonic acids and xylosyl units are components of the side chains of this partially-branched heterorhamnan. The heterorhamnans isolated from G. oxysperma exhibited potent antiviral activity against the herpes simplex virus (HSV-1 and HSV-2), and were devoid of cytotoxic effects at concentrations up to $1000 \mu \mathrm{g} \mathrm{mL}{ }^{-1}$ when assayed on Vero cells [26]. Additionally, the range of biological activity of the heterorhamnans from G. oxysperma and their products (obtained by partial depolymerization) increased as they became cytotoxic against tumoral cells (U87MG). The inhibitory effect on human glioblastoma cells was correlated with the molecular weight and sulfate location of the partially depolymerized products [27]. Indeed, other polysaccharides of seaweed have been tested as antivenom; for example, a sulfated galactan and agaran from Palisada flagellifera and Laurencia aldingensis, respectively, were able to inhibit the toxic effects of Lachesis muta 
venom [28,29]. A fucoidan of the brown seaweed Fucus vesiculosus inhibited the myotoxic activity of some crotaline snake venoms; in these cases, the formation of a complex between fucoidan and isolated myotoxins has been postulated as the mechanism of action for this natural polysaccharide [30]. Surprisingly, smaller fucoidan molecules were not more efficient than larger ones at preventing muscle necrosis [31].

Therefore, we evaluated the effect of G. oxysperma (Go3) sulfated heterorhamnans against some toxic activities of L. muta and B. jararaca venoms.

\section{Results}

\subsection{Inhibition of Go3 on In Vitro Assays of B. jararaca or L. muta Venoms}

L. muta or B. jararaca $\left(2-40 \mu \mathrm{g} \mathrm{mL}^{-1}\right)$ venom induced hemolysis, proteolysis, or coagulation in a concentration-dependent manner. One minimum indirect hemolytic concentration (MIHC; $12 \mu \mathrm{g} \mathrm{mL}^{-1}$ for L. muta and $24 \mu \mathrm{g} \mathrm{mL} \mathrm{m}^{-1}$ for B. jararaca), effective concentration (EC; $5 \mu \mathrm{g} \mathrm{mL^{-1 }}$ for L. muta and 10 $\mu \mathrm{g} \mathrm{mL}{ }^{-1}$ for B. jararaca), or minimum coagulation dose (MCD; $12 \mu \mathrm{g} \mathrm{mL}-1$ for L. muta and $24 \mu \mathrm{g} \mathrm{mL}^{-1}$ for B. jararaca) of venoms was incubated with Go3 (as described in Materials and Methods), and then assays were performed. As shown in Figure 1A, regardless of the venoms tested, the inhibitory profiles of hemolysis by Go3 were similar; around $15 \%$ and $75 \%$ at $1: 10$ and 1:20 venom:Go3 ratios $(w / w)$, respectively. Go3 inhibited B. jararaca proteolysis more efficiently than that of L. muta, since $100 \%$ of $B$. jararaca proteolysis was inhibited at 1:20 venom:Go3 ratio, whereas for L. muta venom, a $60 \%$ inhibition was achieved (Figure 1B). In contrast, the inhibition of coagulation by both venoms by Go3 was less effective, since a delay in coagulation ( $90 \mathrm{~s}$, control value of $60 \mathrm{~s}$ ) only occurred at the highest venom:Go3 ratio, which was 1:50 (Figure 1C). Go3 alone (at concentrations of up to $600 \mu \mathrm{gL}^{-1}$ ) did not cause hemolysis, proteolysis, or coagulation (data not shown).
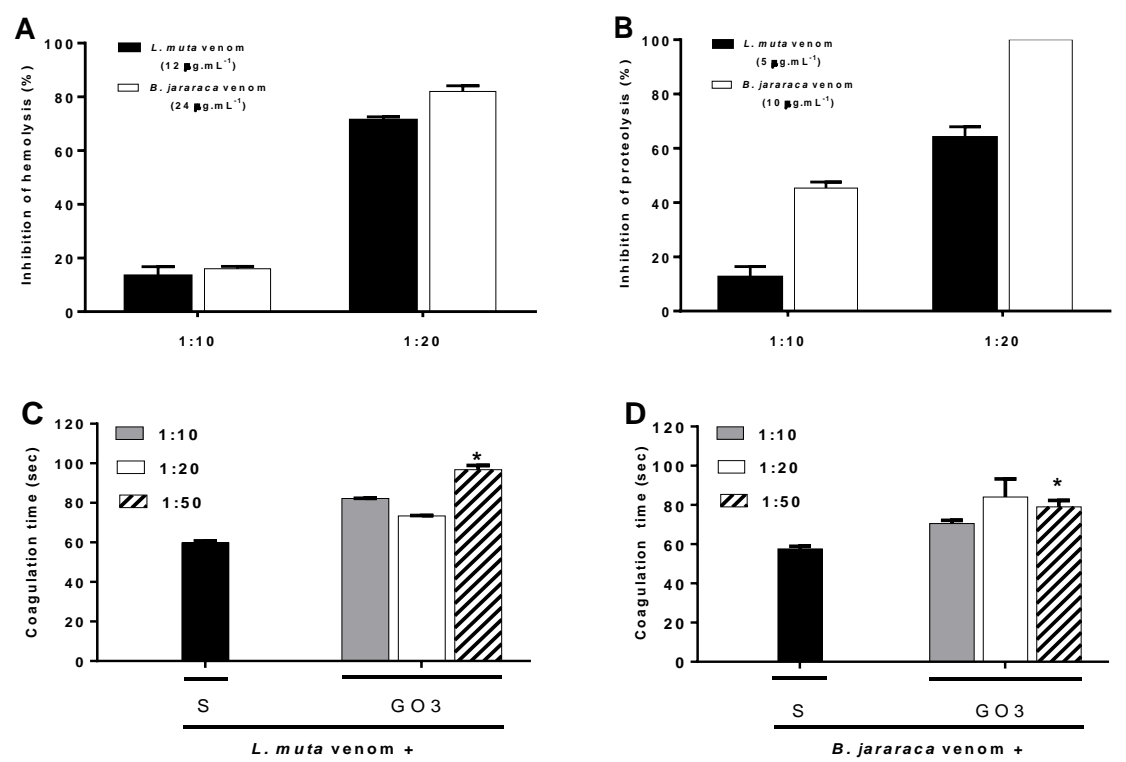

Figure 1. Inhibition by Go3 on in vitro assays of L. muta or B. jararaca venoms. L. muta and B. jararaca venoms were separately incubated with Go3 (1:10 and 1:20 venom:Go3 ratio ( $w / w)$, respectively), and then hemolysis (A) or proteolysis (B) assays were performed. $12 \mu \mathrm{g} \mathrm{mL} \mathrm{m}^{-1}$ of L. muta (C) and $24 \mu \mathrm{g}$ $\mathrm{mL}^{-1}$ of $B$. jararaca (D) venoms (MCD of venoms) were incubated with saline (S) or Go3 (1:10, 1:20 or 1:50, venom:Go3 ratio $(w / w)$ ). Next, mixtures were added to plasma, and coagulation time was monitored. Data are expressed as means \pm S.E. of three individual experiments $(n=3){ }^{*} p<0.05$ when compared to control (black columns). 


\subsection{Inhibition by Go3 of Ex Vivo Plasma Coagulation of L. muta Venom}

The effect of Go3 on plasma coagulation of L. muta venom was evaluated using an ex vivo methodology (Table 1). Mice received a s.c. injection of Go3, saline, or L. muta venom. Two hours later, blood was collected and centrifuged, after which prothrombin time (PT) and activated partial thromboplastin time (aPTT) coagulation tests were performed. Moreover, another experimental approach was evaluated in which L. muta venom was injected s.c., and then followed 30 min later by an i.v. injection of Go3. After $90 \mathrm{~min}$, blood was collected and coagulation tests were performed. As shown in Table 1, plasma did not clot if mice solely received an injection of L. muta venom, while the treatment of mice with Go3 restored plasma coagulation to normal levels in PT and aPTT tests. Injection of only Go3 did not alter plasma coagulation compared to mice that received a saline injection only.

Table 1. Effect of Go3 on the ex vivo coagulation of mouse plasma by L. muta venom.

\begin{tabular}{|c|c|c|}
\hline \multirow{2}{*}{ Groups } & \multicolumn{2}{|c|}{ Coagulation Test (sec) } \\
\hline & aPTT (s) & PT (s) \\
\hline Go3 + saline ${ }^{\mathrm{a}}$ & $44 \pm 0.5^{*}$ & $18 \pm 0.4$ \\
\hline L. muta + saline ${ }^{a}$ & $800 \pm 0.1 *$ & $800 \pm 0.1 *$ \\
\hline L. $m u t a+\mathrm{Go}^{\mathrm{b}}$ & $45 \pm 0.3$ * & $21 \pm 0.4$ \\
\hline Saline ${ }^{a}$ & $27 \pm 0.7$ & $19 \pm 0.6$ \\
\hline
\end{tabular}

\footnotetext{
${ }^{a}$ Mouse groups received a s.c. injection of Go3 with saline, or L. muta venom ( $\left.24 \mu \mathrm{g} / \mathrm{mouse}\right)$ with saline, or saline alone. ${ }^{\mathrm{b}}$ L. muta venom was injected s.c. into mice; 30 min later, Go3 was injected i.v. ${ }^{*}$ Statistical significant difference $(p<0.05$ when compared to saline alone). Results are expressed as the mean $\pm \mathrm{SE}$ of two individual experiments $(n=4)$.
}

\subsection{Neutralization of Hemorrhage and Edema Caused by B. jararaca or L. muta Venoms}

Subcutaneous injection of L. muta ( $24 \mu \mathrm{g} /$ mouse) or B. jararaca ( $30 \mu \mathrm{g} /$ mouse) venom induced a hemorrhage halo of $20 \mathrm{~mm}$, which corresponds to two minimum hemorrhagic doses (MHDs), and such halos were considered to be $100 \%$ of hemorrhagic activity. When mixed with the venoms, Go3 $(140 \mu \mathrm{g} /$ mouse) inhibited $70 \%$ and $40 \%$ of the hemorrhagic activity of L. muta and B. jararaca venoms, respectively (Figure 2A). However, if $L$. muta (black columns) or B. jararaca (white columns) venoms were injected s.c. before (Figure 2B) or after (Figure 2C) the injection of Go3 (orally or i.v.), hemorrhage inhibition also occurred. The inhibitory effect of Go3 was more effective if Go3 was injected exactly at the same site for either L. muta or B. jararaca venoms, even if the Go3 was injected 30 or 60 min after the injection of these venoms (Figure 2D). Thus, the inhibitory effect of Go3 on the hemorrhagic activity of L. muta or B. jararaca venoms was optimal if Go3 was injected s.c. rather than orally or via the i.v. route, which was likely due to being more proximal to the venom injection site.

Since the neutralization of hemorrhagic activity by Go3 was more efficient with L. muta than B. jararaca venom, treatment protocols were only performed for the $L$. muta venom. L. muta venom (24 $\mathrm{\mu g} /$ mouse) was injected s.c., and a single injection (1 injection) or two injections ( 2 injections) of Go3 were given $1 \mathrm{~h}$ later (Figure 3A, treatment protocol). Then, after $6 \mathrm{~h}$ of L. muta venom injection, hemorrhage was analyzed using the method described above. As seen in Figure 3A, a single injection of Go3 inhibited $50 \%$ of L. muta -induced hemorrhage, while two injections of Go3 resulted in an inhibition of $90 \%$. For edema, the injection of $13 \mu \mathrm{g} /$ mouse of $L$. muta or B. jararaca venom into the paw of mice produced an increase of ca. $50 \%$ in paw volume, which was considered as being $100 \%$ of edematogenic activity. Subsequently, a similar dose of L. muta or B. jararaca venom was incubated with Go3 (33 $\mu \mathrm{g} /$ mouse) and then injected s.c. into mice, and then the edema was analyzed using the aforementioned procedure (Figure 3B). As shown in Figure 3B (incubation), Go3 inhibited edema caused by $L$. muta and B. jararaca venoms by ca. $55 \%$ and $15 \%$, respectively. When Go3 was given after the injection of venoms, inhibitory values dropped to approximately $10 \%$ (Figure 3B, treatment). Neither injection of Go3 nor saline induced edema (data not shown). 


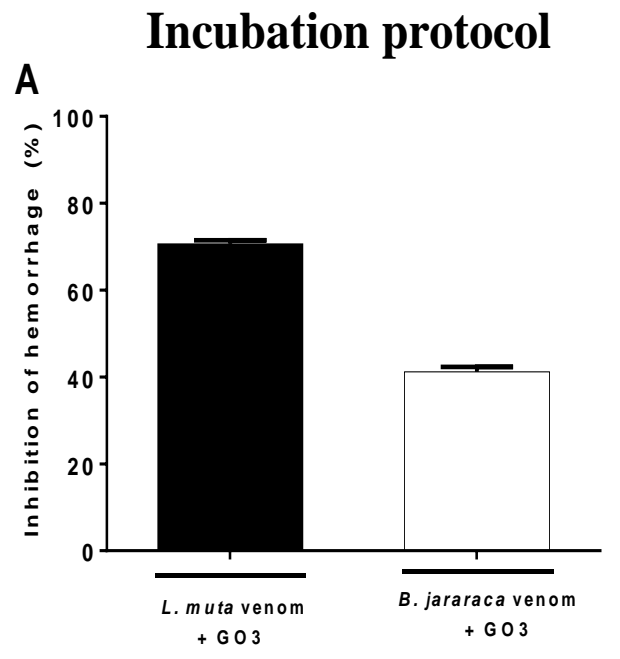

\section{Treatment protocol}

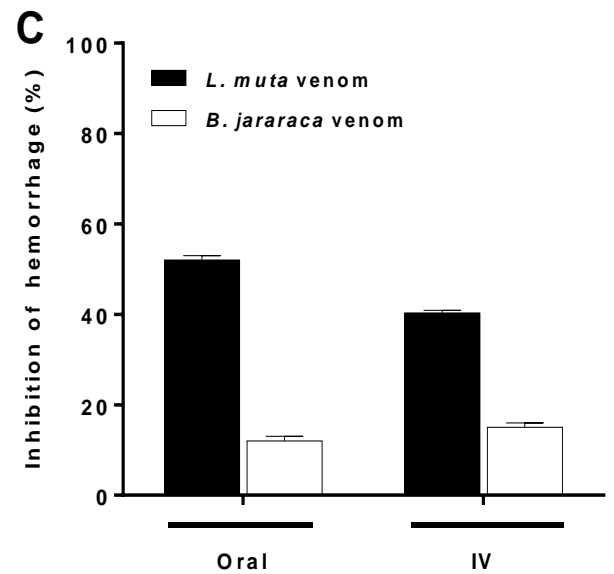

\section{Prevention protocol}

B

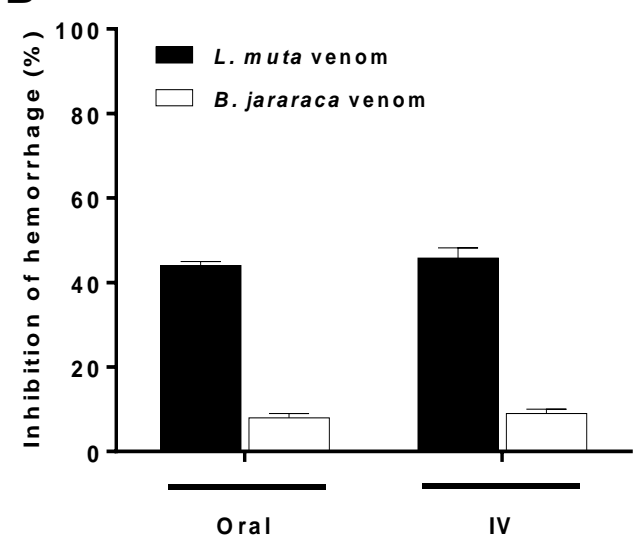

Treatment protocol

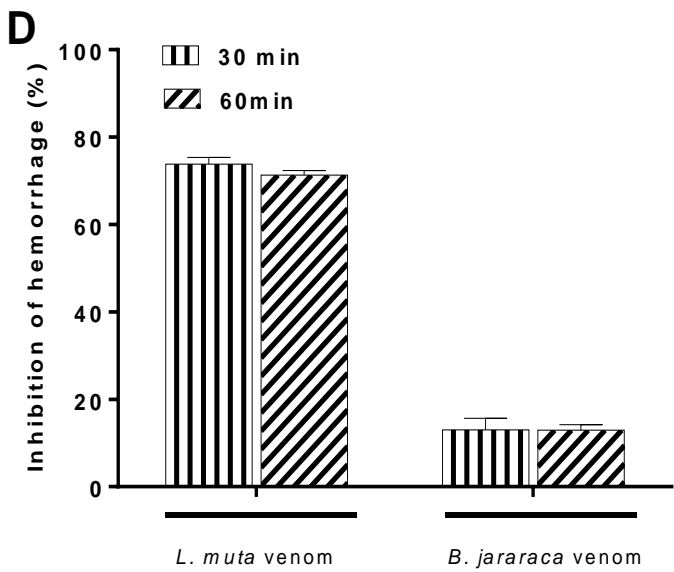

Figure 2. The inhibitory effect of Go3 on hemorrhage caused by L. muta or B. jararaca venoms. (A) Go3 $(140 \mu \mathrm{g} /$ mouse) was incubated with $L$. muta $(24 \mu \mathrm{g} /$ mouse) or B. jararaca (30 $\mu \mathrm{g} / \mathrm{mouse})$ venom for $30 \mathrm{~min}$, and the mixture was then injected s.c. into mice; (B) Go3 was given orally or intravenously (i.v.), and mice received a s.c. injection of L. muta or B. jararaca venom 15 min later; (C) L. muta or B. jararaca venom was given s.c., and Go3 was administered orally or i.v. 15 min later; (D) L. muta or B. jararaca venom was injected s.c., and Go3 was injected s.c. 30 or $60 \mathrm{~min}$ later. Data are expressed as the mean \pm SE of individual experiments $(n=5)$.

\subsection{Neutralization of B. jararaca Venom Lethality by Go3}

Despite injecting large amounts of venom into victims, the lethal activity of L. muta venom is relatively weak. Thus, lethality was only tested with the venom of $B$. jararaca. Mice that received a single injection i.p. of $B$. jararaca venom (14 $\mu$ g/mouse) mixed with saline died at 110 min (Table 2). In contrast, when B. jararaca venom was incubated with Go3 (140 $\mu \mathrm{g} / \mathrm{mouse})$ followed by i.p. injection of the mixture into mice, deaths occurred at $350 \mathrm{~min}$. Go3 also delayed mice from death even when the Go3 injection was performed 15 or 30 min before (prevention protocol) or after (treatment protocol) injection of $B$. jararaca venom, and this neutralization efficacy was quite similar in both protocols (Table 2). Injection of only saline or Go3 (concentrations up to $500 \mu \mathrm{g} / \mathrm{mouse}$ ) did not kill the mice (data not shown). 


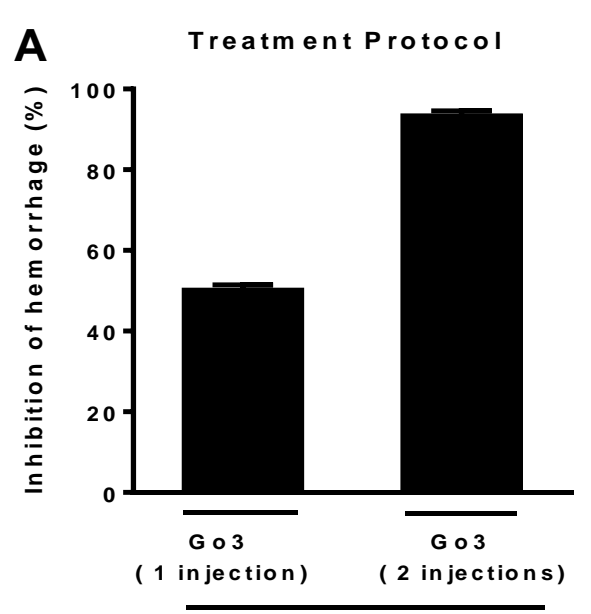

L. muta venom+

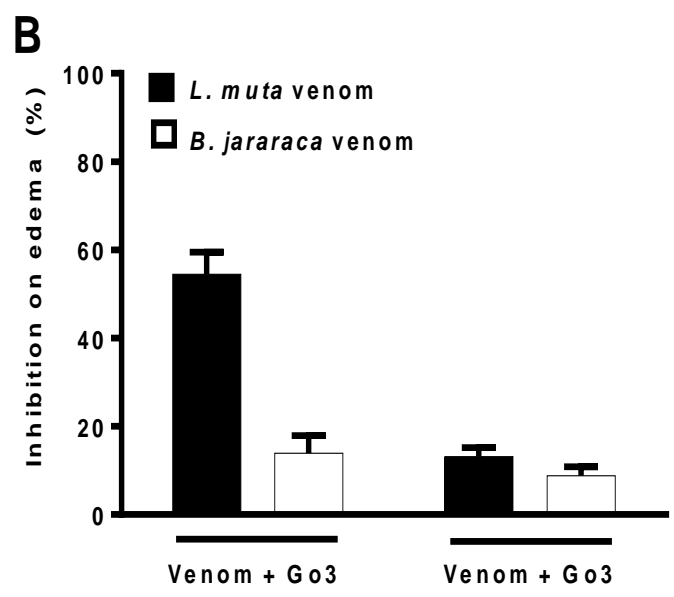

(Incubation)

(Treatment)

Figure 3. The inhibitory effect of Go3 on hemorrhage and edema caused by L. muta and B. jararaca venoms. (A) $L$. muta venom ( $24 \mu \mathrm{g} /$ mouse) was given s.c. to mice, and then one or two injections i.v. of Go3 $(140 \mu \mathrm{g} /$ mouse) were performed (treatment protocol) $1 \mathrm{~h}$ later. $6 \mathrm{~h}$ after L. muta venom injection, hemorrhagic activity was measured using the aforementioned procedure; (B) At the incubation protocol, $13 \mu \mathrm{g} /$ mouse of L. muta or B. jararaca venoms were incubated with $33 \mu \mathrm{g} / \mathrm{mouse}$ Go3, and mixture was then injected into mice. As part of the treatment protocol, L. muta (black column) or B. jararaca (white column) venom was injected s.c. into mice, and then mice received injection i.v. of Go3 15 min later. Edema was analyzed thereafter using the aforementioned procedure. Data are expressed as the mean $\pm \mathrm{SE}$ of individual experiments $(\mathrm{n}=5)$.

Table 2. The protective effect of Go3 on lethality produced by B. jararaca venom.

\begin{tabular}{|c|c|c|c|c|c|}
\hline \multirow{3}{*}{ Groups } & \multicolumn{5}{|c|}{ Survival Time for Different Protocols (min) } \\
\hline & \multirow{2}{*}{$\frac{\text { Incubation }^{\mathrm{a}}}{30 \mathrm{~min}}$} & \multicolumn{2}{|c|}{ Prevention $^{b}$} & \multicolumn{2}{|c|}{ Treatment $^{c}$} \\
\hline & & $15 \mathrm{~min}$ & $30 \mathrm{~min}$ & $15 \mathrm{~min}$ & $30 \mathrm{~min}$ \\
\hline B. jararaca venom + saline & $110 \pm 20$ & $101 \pm 15$ & $101 \pm 11$ & $101 \pm 17$ & $101 \pm 18$ \\
\hline B. jararaca venom + Go3 & $350 \pm 25^{*}$ & $205 \pm 27 *$ & $215 \pm 17 *$ & $206 \pm 21 *$ & $189 \pm 22 *$ \\
\hline
\end{tabular}

a B. jararaca venom (14 $\mathrm{gg} /$ mouse) was incubated with saline or with Go3 $(140 \mu \mathrm{g} / \mathrm{mouse})$ for $30 \mathrm{~min}$ at $25^{\circ} \mathrm{C}$, and then the mixture was injected i.p. into mice; ${ }^{b} \mathrm{Go} 3$ was injected i.p., and B. jararaca venom was injected 15 or $30 \mathrm{~min}$ later via the same route; ${ }^{c}$ B. jararaca venom was injected i.p., and Go3 was injected 15 or 30 min later via the same route; ${ }^{b, c}$ Results are expressed as the mean \pm SE of two individual experiments $(n=6) .{ }^{*} p<0.05$ when compared to $B$. jararaca + saline.

\subsection{Neutralization L. muta Venom Myotoxicity by Go3}

Myotoxic activity was not performed for B. jararaca venom due to its low myotoxicity. As previously described, muscular tissue necrosis in victims caused by snakebite is directly associated with groups of enzymes of snake venoms, as low molecular weight basic toxins, phospholipase $\mathrm{A}_{2}$, hemorrhagic myotoxins, and cardiotoxins. The myotoxic activity of L. muta venom was analyzed through the release of creatine kinase (CK) from mice plasma. Injection i.m. of L. muta venom (15 $\mathrm{gg} /$ mouse) mixed with saline (S) produced a release of CK of the muscle of mice at of $950 \mathrm{U} \mathrm{L}^{-1}$ (Figure 4, incubation). When L. muta venom was mixed with Go3 (140 $\mu \mathrm{g} / \mathrm{mouse})$, the myotoxic activity of the venom was fully inhibited, since no trace of CK was detected (Figure 4, incubation). In another set of experiments (treatment), L. muta venom was injected i.m., and Go3 or saline (S) was injected $15 \mathrm{~min}$ later at the same site of the venom injection, with myotoxicity being evaluated thereafter. As seen in Figure 4, Go3 continued to protect mice from L. muta venom-induced myotoxicity through the treatment protocol. The injection of Go3 or saline only did not induce the release of CK of plasma in mice. 


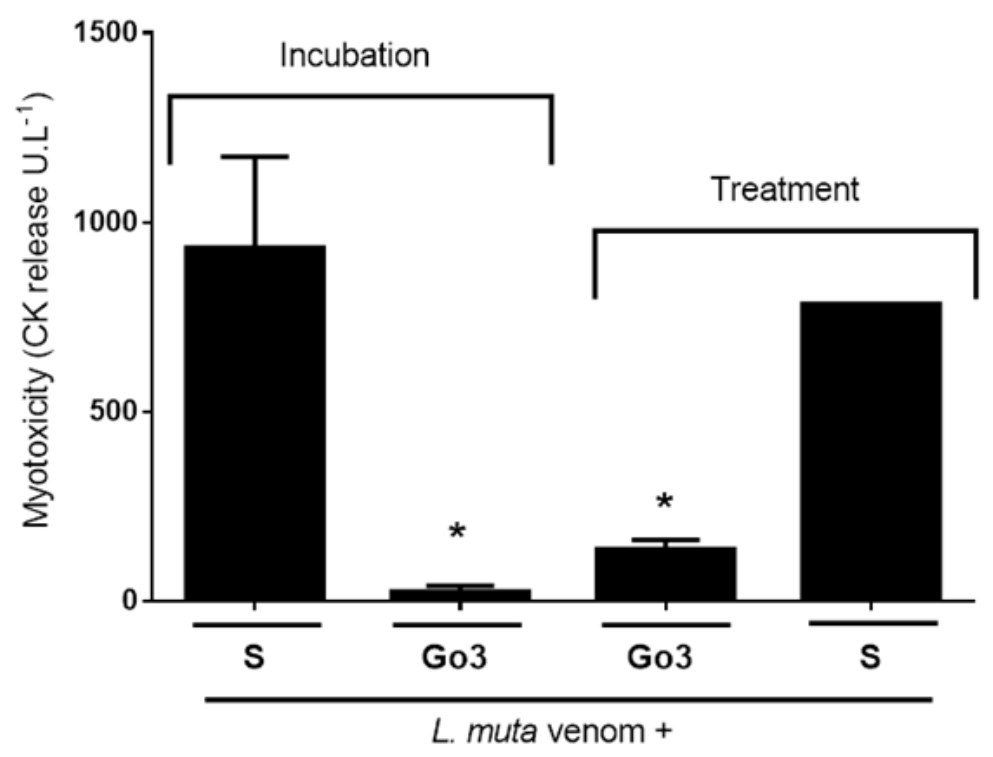

Figure 4. The effect of Go3 on myotoxicity caused by L. muta venom. For the incubation protocol, L. muta venom ( $15 \mu \mathrm{g} /$ mouse) was incubated with saline (S) or with Go3 (140 $\mu \mathrm{g} /$ mouse), the mixtures were then injected into mice, and myotoxicity was analyzed by measuring CK release from mice plasma (expressed as $\mathrm{U} \mathrm{L}^{-1}$ ). Alternatively (treatment protocol), L. muta venom was injected i.m., and Go3 or saline (S) was injected i.m. at the same site of the venom injection 15 min later. CK release was then measured as described. Data are expressed as the mean \pm SE of individual experiments $(n=5)$. * $p<0.05$ when compared to L. muta + saline (S).

\section{Discussion}

The incidence and mortality indices of snakebites are higher than other neglected diseases, such as dengue, cholera, Chagas disease, leishmaniasis, yellow fever, and schistosomiasis [1,2]. Due to the unsatisfactory efficacy of classical antivenoms to counteract the local effects of venoms such as massive tissue necrosis [32,33], alternative treatments should be explored further, with natural organisms providing a good source of innovative bioactive molecules [13,14,34,35]. In general, the official protocol performed to test antivenoms involves incubating them with venoms and then injecting the mixture into mice to determine lethality. Undoubtedly, such procedures do not reflect a real situation of envenomation through snakebite, in which the venom is injected into victims and antivenom is administered afterwards. In fact, such a protocol may facilitate the inhibitory efficacy of antivenoms.

The present work demonstrated, for the first time, a sulfated heterorhamnans from a marine alga (Go3) being able to neutralize some of the in vivo activities (hemorrhage, edema, lethality, and myotoxicity) induced by B. jararaca and L. muta venoms. This is in contrast to both Brazilian antivenoms, which do not efficiently block tissue necrosis and other local effects of $B$. jararaca or B. jararacussu venoms (e.g., hemorrhage and inflammation) at clinical doses [36]. However, the inhibition of such in vivo activities was achieved only at higher concentrations of antivenom-nearly 10 times the dose used in cases of envenomation by Bothrops in Brazil [36,37]. With this in mind, pharmacokinetic and pharmacodynamic approaches should be performed to discover how Go3 acts in organisms, as well as the Go3 dosage necessary to treat victims. Understanding the observed neutralizing effect of Go3 remains an important task in the field of toxinology, since venom-induced edema, hemorrhage, and myotoxicity may lead to amputation and deformity; these effects are the main hazardous symptoms following snakebites and contribute to the progression of tissue damage. Go3 may prevent tissue necrosis induced by snakebite. The most notable result of this work relies on one chemical structure neutralizing different enzymes or active components of both venoms, and the inhibition of Go3 also occurring through two experimental protocols; the first was developed to more closely simulate a real envenomation (treatment), while the second protocol (prevention) was performed to provide 
prior protection to victims from the toxic effects of envenomation. In addition, regardless of the Go3 administration route, in vivo activities were also inhibited. The inhibition of toxic effects caused by the venom of the L. muta snake by other sulfated polysaccharides obtained from seaweeds was previously reported for sulfated galactans, and was correlated with possible interactions due to the negative and positive charges present in sulfated galactans and in the proteins present in snake venoms, respectively $[28,29]$. Additionally, a sulfated fucoidan from Fucus vesiculosus exhibited a protective effect against the cytotoxic and myotoxic effects of myotoxins from crotaline snake venoms [30,31], with a reduction in the molecular weight of fucoidan being accompanied by a reduction in antivenom activity. Therefore, higher molecular weights of such polysaccharides resulted in more efficient inhibition [31].

In particular, the inhibitory mechanism of action of Go3 should be investigated through binding to divalent metals such as $\mathrm{Ca}^{2+}$ or $\mathrm{Zn}^{2+}$. These metals should be considered because of their anionic charges, as well as their molecular weights. Most of the active enzymes in venoms require divalent metals to induce their toxic activities [37]. However, regardless of the inhibition mechanism, Go3 may be effective against other species of Bothrops or Crotalus, as their venom composition is quite similar. The structural features (molecular weight, glycoside linkage, sugar composition, and the content of sulfate groups) are critical for polysaccharides to display pharmacological activities $[19,22,38,39]$. This is true for polysaccharides isolated from green seaweeds, in which the presence of 2-linked rhamnosyl units that are 3,4-sulfated allows the binding to target on plasma membrane or intracellular proteins of tissues [24]. The literature also indicated that sulfated polysaccharides from seaweeds have little to no cytotoxicity to cells [40], and could thus be good antivenom candidates.

\section{Materials and Methods}

\subsection{Snake Venom, Animals, and Other Materials}

The venoms of L. muta and B. jararaca were kindly supplied by Fundação Ezequiel Dias (FUNED), Belo Horizonte, Minas Gerais State, Brazil, and stored at $-20^{\circ} \mathrm{C}$ until use. Balb/c mice (18-20 g) were obtained from the Núcleo de Animais de Laboratório (NAL) of the Federal Fluminense University (UFF), and were housed under constant temperature $\left(24 \pm 1^{\circ} \mathrm{C}\right)$ and light conditions. Experiments were approved by the UFF Institutional Committee for Ethics in Animal Experimentation (protocol number 25), which are in accordance with the guidelines of the Brazilian Committee for Animal Experimentation (COBEA). All reagents were of the best available grade.

\subsection{Collection of G. oxysperma Specimens}

Specimens of G. oxysperma (Kützing) K. L. Vinogradova ex Scagem et al. were collected on the southern coast of Brazil (Bahia de Paranaguá, Paraná State). An exemplar specimen was deposited at the herbarium of the Federal University of Paraná (Curitiba, Brazil) under the herbarium identification code UPCB-58059.

\subsection{Extraction and Purification of Go3 Sulfated Heterorhamnans Fraction}

The algal material was cleaned, washed with tap water, sun-dried, and milled. The polysaccharides were extracted as previously described [26,27]. Briefly, dried and milled G. oxysperma was extracted twice with water $(5 \%, w / v)$ at $25{ }^{\circ} \mathrm{C}$ for $4 \mathrm{~h}$ under mechanical stirring. After centrifugation, the supernatant was treated with ethanol $(\mathrm{EtOH})(3: 1, v / v)$, and the $\mathrm{EtOH}$ - precipitated material was redissolved in distilled water, dialyzed (cut-off at 12-14 kDa), concentrated by rotary evaporation under reduced pressure, and freeze-dried, giving rise to the polysaccharide extract named "Go1" (1.4\% yield, based on dried and milled seaweed). This entire process was repeated to create Go2 extract ( $0.6 \%$ yield). The algal residue obtained from extractions at $25{ }^{\circ} \mathrm{C}$ was then submitted to similar aqueous extraction at $80{ }^{\circ} \mathrm{C}$, giving rise to the Go3 fraction $(13.8 \%$ yield). The sulfated 
heterorhamnans Go3 $(10 \mathrm{mg})$ was resuspended in $1 \mathrm{~mL}$ of saline, aliquoted, and stored at $-20^{\circ} \mathrm{C}$ until assays were performed.

\subsection{In Vitro Assays}

\subsubsection{Antihemolytic Activity}

The degree of hemolysis caused by L. muta or B. jararaca venom was determined by indirect hemolytic test using human erythrocytes and hen's egg yolk emulsion as substrate that contains phospholipids [41]. After incubating venoms with substrate (phospholipids) for $15 \mathrm{~min}$ at $37^{\circ} \mathrm{C}$, the reaction was stopped by adding EDTA ( $8 \mathrm{mM}$, final concentration). Then, a washed red blood cells suspension $(2 \% v / v)$ was added to the reaction medium and tubes were incubated for $1 \mathrm{~h}$ at $37^{\circ} \mathrm{C}$. At this moment, lysolecithin formed during the enzymatic reaction lyzed cells, tubes were centrifuged at $2000 \mathrm{rpm}$ for $10 \mathrm{~min}$, and released hemoglobin was measured at Absorbance $578 \mathrm{~nm}$. After creating a concentration-response curve, the amount of venom $\left(\mu \mathrm{g} \mathrm{mL}^{-1}\right)$ capable of inducing $100 \%$ of hemolysis was denoted as the minimum inhibitory hemolytic concentration (MIHC). Then, one MIHC of L. muta $\left(12 \mu \mathrm{g} \mathrm{mL}{ }^{-1}\right)$ or B. jararaca $\left(24 \mu \mathrm{g} \mathrm{mL}^{-1}\right)$ venom was incubated with Go3 (at 1:10 or 1:20 w/w, venom:Go3) for $30 \mathrm{~min}$. at $25^{\circ} \mathrm{C}$, followed by the hemolytic test. Control experiments were performed by incubating venoms with saline in the absence of Go3, or by adding Go3 alone to reaction medium.

\subsubsection{Antiproteolytic Activity}

The proteolytic activity of L. muta or B. jararaca venom was determined as in [42], using azocasein (obtained from Sigma Chemical Co., St. Louis, MO, USA) as a substrate $(0.2 \% w / v$ in $20 \mathrm{mM}$ Tris-HCl, $8 \mathrm{mM} \mathrm{CaCl}_{2}, \mathrm{pH} \mathrm{8.8)}$ with modifications. Different venom concentrations were incubated with $0.4 \mathrm{~mL}$ azocasein at $37^{\circ} \mathrm{C}$ for $90 \mathrm{~min}$ in a total volume of $1.2 \mathrm{~mL}$. The enzymatic reaction was stopped by the addition of trichloracetic acid ( $5 \% v / v$, final concentration). The tubes were centrifuged at $15,000 \times g$ for $3 \mathrm{~min}$. The supernatant was then removed and mixed with $2 \mathrm{M} \mathrm{NaOH}$, and the tubes were read at Absorbance (A) $420 \mathrm{~nm}$ to measure the release of azo dye. The effective concentration (EC) was defined as the amount of venom $\left(\mu \mathrm{g} \mathrm{mL}^{-1}\right)$ able to produce a variation of 0.2 units at $\mathrm{A} 420 \mathrm{~nm}$. For the inhibitory experiments, one EC of each venom $\left(5 \mu \mathrm{g} \mathrm{mL}-1\right.$ for L. muta and $10 \mu \mathrm{g} \mathrm{mL} \mathrm{m}^{-1}$ for B. jararaca) was incubated with Go3. Proteolytic activity was then determined accordingly.

\subsubsection{Anticoagulant Activity}

Different concentrations of B. jararaca or L. muta venom were added to plasma, and coagulation time was monitored using a digital Amelung coagulometer (model KC4A, Labcon, Germany). The amount of venom $\left(\mu \mathrm{g} \mathrm{mL}^{-1}\right.$ ) able to clot plasma around $60 \mathrm{~s}$ was called minimum coagulation dose (MCD), and venom (L. muta, $12 \mu \mathrm{g} \mathrm{mL}^{-1}$ or B. jararaca, $24 \mu \mathrm{g} \mathrm{mL}^{-1}$ ) was incubated with different concentrations of Go3, resulting in venom:Go3 ratios $(w / w)$ of $1: 10,1: 20$ or 1:50 for $30 \mathrm{~min}$ at $25^{\circ} \mathrm{C}$. Following incubation, this mixture was added to the reaction medium and coagulation was monitored as previously described above. Controls were performed by adding Go3 or saline with plasma in the absence of venom.

\subsubsection{Ex Vivo Coagulation Tests}

Three different experimental groups were performed, as follows: (a) L. muta (24 $\mu \mathrm{g} / \mathrm{mouse})$ venom was administered subcutaneously (s.c.) into the abdomen cavity of mice; (b) Go3 (140 $\mu \mathrm{g} / \mathrm{mouse}$ ) or saline was administered intravenously (i.v.); or (c) L. muta venom was administered s.c., and Go3 was injected i.v. $30 \mathrm{~min}$ later. Regardless of the experimental group, animals were euthanized after $2 \mathrm{~h}$ and blood was collected by cardiac puncture using citrate as anticoagulant. Blood was centrifuged at $1800 \mathrm{~g}$ for $10 \mathrm{~min}$, and plasma was transferred to plastic tubes. Then, prothrombin time (PT) or activated partial thromboplastin time (aPTT) tests were performed according to the manufacturer's instructions 
(Wiener Laboratories, Rosario, Argentina). For PT, an aliquot (50 $\mu \mathrm{L})$ of plasma was incubated for $1 \mathrm{~min}$ at $37^{\circ} \mathrm{C}$, and then $100 \mu \mathrm{L}$ of pre-warmed thromboplastin with calcium were added to initiate coagulation. For the aPTT test, plasma was incubated for $1 \mathrm{~min}$ at $37^{\circ} \mathrm{C}$ with $100 \mu \mathrm{L}$ of the aPTT reagent and cephalin plus kaolin for a final volume of $200 \mu \mathrm{L}$. Coagulation was then triggered by adding $\mathrm{CaCl}_{2}(8.3 \mathrm{mM}$, final concentration) and monitored on the coagulometer.

\subsection{In Vivo Assays}

\subsubsection{Antihemorrhagic Activity}

Hemorrhagic lesions produced by L. muta or B. jararaca venom were quantified using a procedure described by [43], with some modifications. B. jararaca or L. muta venom was injected intradermally (i.d.) into the abdominal skin of mice, and animals were euthanized by decapitation $2 \mathrm{~h}$ later. The abdominal skin was removed, stretched, and inspected for visual changes in the internal aspect in order to localize hemorrhagic areas. One minimum hemorrhagic dose (MHD) was defined as the amount of venom ( $\mu \mathrm{g} / \mathrm{mouse}$ ) able to produce a hemorrhagic halo of $10 \mathrm{~mm}$, which was 12 and $15 \mu \mathrm{g} /$ mouse for L. muta and B. jararaca venom, respectively. To analyze the effect of Go3 on venom-induced hemorrhaging, three protocols were employed: (a) incubation: Go3 was mixed with $L$. muta ( $24 \mu \mathrm{g} / \mathrm{mouse}$ ) or B. jararaca ( $30 \mu \mathrm{g} /$ mouse) venom for $30 \mathrm{~min}$ at $25^{\circ} \mathrm{C}$, and the mixture was then injected i.d. into mice; (b) prevention: Go3 was administered orally or i.v., and venom was injected s.c. into mice 15 min later; (c) treatment, venom was injected s.c., and Go3 was administered orally or i.v. $15 \mathrm{~min}$ later. Additionally, venom was injected s.c., and Go3 was injected s.c. at the site of venom injection 30 or 60 min later.

Moreover, two additional sets of experiments were performed: (a) L. muta venom was injected s.c., and Go3 was administered i.v. $1 \mathrm{~h}$ later. After $6 \mathrm{~h}$, animals were euthanized and hemorrhagic activity was assessed; (b) L. muta venom was injected s.c., and Go3 was injected i.v. 1 or 2 h later. After 6 h, animals were euthanized and hemorrhagic activity was assessed. Negative controls were performed by injecting solely saline or Go3 instead of venom. The volume of sample injections into mice was $100 \mu \mathrm{L}$.

\subsubsection{Antiedematogenic Activity}

The edema-inducing activity of venom was determined according to [44] with some modifications. Groups of five mice received a single s.c. sub plantar injection of $50 \mu \mathrm{L}$ of L. muta or B. jararaca venom into the right paw, while the left paw received $50 \mu \mathrm{L}$ of saline. Then, edema was evaluated $1 \mathrm{~h}$ after injection and expressed as the percentage increase in the weight of the right paw (ca. 50\%) compared to the left one. The effect of Go3 was evaluated by mixing venoms with Go3 for $30 \mathrm{~min}$ at $25^{\circ} \mathrm{C}$, followed by the mixture $(50 \mu \mathrm{L})$ being injected s.c. into animals. Additionally, the protocol for treatment was employed, in which L. muta or B. jararaca venom was injected s.c., and Go3 was injected i.v. 15 min later. Edema was then measured. The control group was injected with Go3 or saline in the absence of venom.

\subsubsection{Antilethality Activity}

The antilethality assay was performed by incubating B. jararaca venom ( $14 \mu \mathrm{g} / \mathrm{mouse})$ with Go3 ( $140 \mu \mathrm{g} /$ mouse) for $30 \mathrm{~min}$ at $25^{\circ} \mathrm{C}$, followed by the mixture being injected i.p. into mice. Positive groups received $B$. jararaca venom mixed with saline, while the negative control received solely Go3 or saline instead of venom. Similarly, two other protocols were also performed: (a) treatment: B. jararaca venom was injected i.p., and Go3 was injected via the same route 15 or 30 min later; and (b) prevention: Go3 was injected i.p., and B. jararaca venom was injected i.p. 15 or $30 \mathrm{~min}$ later. After the end of injections, the number of deaths was observed over a period of $24 \mathrm{~h}$. The injection volume of samples was $100 \mu \mathrm{L}$. 


\subsubsection{Antimyotoxic Activity}

L. muta venom or saline was injected $(50 \mu \mathrm{L})$ intramuscularly (i.m.) into mice under the right tibial anterior muscles, so that the injected site was positioned just over the extensor digitorum longus (EDL) muscle [45]. After $2 \mathrm{~h}$, blood was collected and the serum was separated by centrifugation and stored at $4{ }^{\circ} \mathrm{C}$ for subsequent determination of the plasma CK activity using a diagnostic kit (Sigma Chemical Co., Saint Louis, MO, USA). The rate of CK release from the isolated muscles was expressed as the increase in CK release compared to control values (mice that received a saline injection or did not receive any other injection). CK activity was expressed as international units (U), where $1 \mathrm{U}$ is the enzyme amount that catalyzes the transformation of $1 \mu \mathrm{mol}$ of substrate at $25^{\circ} \mathrm{C}$. The rate of $\mathrm{CK}$ release from the isolated muscle was expressed as enzyme units released into the medium per gram per h of collection (U/g h), as previously reported [45]. Myotoxicity was then expressed as the increase of released CK. The inhibitory effect of Go3 was assessed using the following protocols: (a) incubation: L. muta venom $\left(15 \mu \mathrm{g} \mathrm{mL}{ }^{-1}\right)$ was incubated with Go3 $\left(140 \mu \mathrm{g} \mathrm{mL}{ }^{-1}\right)$ or saline for $30 \mathrm{~min}$ at $25^{\circ} \mathrm{C}$, and the mixture $(50 \mu \mathrm{L})$ was then injected i.m. into mice; (b) treatment: L. muta venom $(50 \mu \mathrm{L})$ was injected i.m., and Go3 $(50 \mu \mathrm{L})$ was injected i.m. at the venom injection site $15 \mathrm{~min}$ later. The negative control was performed by injecting saline instead of Go3, and myotoxicity was determined $2 \mathrm{~h}$ later, as described here.

\subsection{Statistical Analysis}

Results were expressed as the mean \pm SE obtained from the number of animals or experiments performed. The statistical significance of differences among experimental groups was evaluated using the Student's $t$-test. $p$ values $<0.05$ were considered significant.

\section{Conclusions}

Overall, Go3 appeared to inhibit the primary toxic activities of B. jararaca and L. muta venom. These results suggest that the use of Go3 as medicine or phytotherapy to improve antivenom therapy could prevent or diminish the effects of local necrosis that cause severe disabilities, disfigurement, or mortality among snakebite victims. In order to achieve this goal, the development of dosage forms (as cream, gel, capsule, patch or pill) using Go3 should be investigated further.

Author Contributions: Conceptualization, A.C.R.S., M.E.D. and A.L.F.; Methodology, A.C.R.S., L.G.F., J.E.F.C. and A.L.F.; Validation, A.C.R.S., M.E.D., E.F.S. and A.L.F.; Formal Analysis, A.C.R.S., E.F.S. and A.L.F.; Investigation, A.C.R.S. and A.L.F.; Resources, M.E.D., E.F.S., M.D.N. and A.L.F.; Data Curation, A.C.R.S. and A.L.F.; Writing-Original Draft Preparation, A.C.R.S., L.G.F., M.E.D. and A.L.F.; Writing-Review \& Editing, M.E.D. and A.L.F.; Visualization, A.C.R.S., M.E.D., M.D.N., E.F.S. and A.L.F.; Supervision, A.L.F.; Project Administration, A.L.F.; Funding Acquisition, M.E.D., M.D.N. and A.L.F.

Funding: This research was funded by grants of International Foundation for Science (Grant F/4571-1), and the Brazilian agencies: Conselho Nacional de Desenvolvimento Científico e Tecnológico (CNPq), Fundação de Amparo à Pesquisa do Estado do Rio de Janeiro Carlos Chagas Filho (FAPERJ, No: E-26/201.163/2014). Fundação de Amparo a Pesquisa do Estado de Minas Gerais, (FAPEMIG, Grant No: CBB APQ 01791-10), Fundação Araucária/CNPq.

Acknowledgments: J.E.F.C. acknowledges a doctoral scholarship from CAPES, A.C.R.S. and L.G.F. acknowledge a post doctoral scholarship from FAPERJ and CAPES, respectively. A.L.F., E.F.S., M.E.D. and M.D.N. are Research Members of the National Research Council of Brazil (CNPq). A.L.F. acknowledges Universidade Federal Fluminense/Pró-reitoria de Pós-graduação, Pesquisa e Inovação (UFF/PROPPI). The authors thank Norman Ratcliffe, from the Swansea University, United Kingdom, for kindly revising the manuscript.

Conflicts of Interest: The authors declare no conflict of interest. "The funders had no role in the design of the study; in the collection, analyses, or interpretation of data; in the writing of the manuscript, and in the decision to publish the results". 


\section{References}

1. Warrel, D.A. Snake bite. Lancet 2010, 375, 77-88. [CrossRef]

2. Williams, D.; Gutiérrez, J.M.; Harrison, R.; Warrell, D.A.; White, J.; Winkel, K.D.; Gopalakrishnakone, P. The Global Snake Bite Initiative: An antidote for snake bite. Lancet 2010, 375, 89-91. [CrossRef]

3. Jeane, R.B.; Monteiro, H.S.A.; Machado, L.G.; Guarnieri, M.C.; Ximenes, R.M.; Nojosa, D.M.B.; Luna, K.P.O.; Zingali, R.B.; Netto, C.C.; Gutiérrez, J.M.; et al. Venomics and antivenomics of Bothrops erythromelas from five geographic populations within the Caatinga ecoregion of northeastern Brazil. J. Proteomics 2015, 114, 93-114.

4. Warrell, D.A. Snakebites in Central and South America: Epidemiology, clinical features, and clinical management. In The Venomous Reptiles of the Western Hemisphere; Campbell, J.A., Lamar, W.W., Eds.; Comstock Publishing Associates: Ithaca, NY, USA; London, UK, 2004; Volume 2, pp. 709-761.

5. Bertolozi, M.R.; Scalena, C.M.A.; França, F.O.S. Vulnerabilities in snakebites in São Paulo, Brazil. Rev. Saúde Pública 2015, 49, 82-88. [CrossRef] [PubMed]

6. Gutiérrez, J.M.; Leon, G.; Burnouf, T. Antivenoms for the treatment of snakebite envenomings: The road ahead. Biologicals 2011, 39, 129-142. [CrossRef] [PubMed]

7. Chaves, F.; Loria, G.D.; Salazar, A.; Gutiérrez, J.M. Intramuscular administration of antivenoms in experimental envenomation by Bothrops asper: Comparison between Fab and IgG. Toxicon 2003, 41, 237-244. [CrossRef]

8. Kemparaju, K.; Girish, K.S.; Nagaraju, S. Hyaluronidases, a Neglected Class of Glycosidases from Snake Venom Beyond a Spreading Factor. In Handbook of Venoms and Toxins of Reptiles; Mackessy, S.P., Ed.; CRC Press, Taylor \& Francis Group: Boca Raton, FL, USA, 2010; pp. 237-254.

9. Chippaux, J.P.; Goyffon, M. Antivenoms and immunotherapy. Toxicon 1998, 36, 823-846. [CrossRef]

10. Knudsen, C.; Laustsen, A.H. Recent Advances in Next Generation Snakebite Antivenoms. Trop. Med. Infect. Dis. 2018, 3, 42. [CrossRef] [PubMed]

11. Luiz, M.B.; Pereira, S.S.; Prado, N.D.R.; Gonçalves, N.R.; Kayano, A.M.; Moreira-Dill, L.S.; Sobrinho, J.C.; Zanchi, F.B.; Fuly, A.L.; Fernandes, C.F.; et al. Camelid Single-Domain Antibodies (VHHs) against Crotoxin: A Basis for Developing Modular Building Blocks for the Enhancement of Treatment or Diagnosis of Crotalic Envenoming. Toxins 2018, 10, 142. [CrossRef] [PubMed]

12. Laustsen, A.H.; Dorrestijn, N. Integrating Engineering, Manufacturing, and Regulatory Considerations in the Development of Novel Antivenoms. Toxins 2018, 10, 309. [CrossRef] [PubMed]

13. Mohammad, F.F.; James, R.K.; Rashedul, M.A.; Syeda, R.J.; Mahbub, S.; Mia, M.M.K. Ethnopharmacological Survey of Medicinal Plants Used by Traditional Healers and Indigenous People in Chittagong Hill Tracts, Bangladesh, for the Treatment of Snakebite. Evid. Based Complement. Alternat. Med. 2015, 23, 871-875.

14. Blunt, J.W.; Copp, B.R.; Keyzers, R.A.; Munro, M.H.G.; Prinsep, M.R. Marine natural products. Nat. Prod. Rep. 2014, 31, 160-258. [CrossRef] [PubMed]

15. Ivanova, V.R.; Rouseva, M.; Kolarova, J.; Serkedjieva, R.; Rachel, V.; Maolova, N. Isolation of a polysaccharide with antiviral effect from Ulva lactuca. Prep. Biochem. 1994, 242, 83-97. [CrossRef]

16. Lee, J.B.; Hayashi, K.; Hayashi, T.; Sankawa, U.; Maeda, M. Antiviral activities against HSV-1, HCMV, and HIV-1 of rhamnan sulfate from Monostroma latissimum. Planta Med. 1999, 65, 439-441. [CrossRef] [PubMed]

17. Lee, J.B.; Hayashi, K.; Maeda, M.; Hayashi, T. Antiherpetic activities of sulfated polysaccharides from green algae. Planta Med. 2004, 70, 813-817. [CrossRef] [PubMed]

18. Harada, N.; Maeda, M. Chemical structure of antithrombin-active Rhamnan sulfate from Monostrom nitidum. Biosci. Biotechnol. Biochem. 1998, 62, 1647-1652. [CrossRef] [PubMed]

19. Zhang, H.J.; Mao, W.J.; Fang, F.; LI, H.Y.; SUN, H.H.; Chen, Y.; Qi, X.H. Chemical characteristics and anticoagulant activities of a sulfated polysaccharide and its fragments from Monostroma latissimum. Carbohydr. Polym. 2008, 71, 428-434. [CrossRef]

20. Qi, H.; Zhang, Q.; Zhao, T.; Hu, R.; Zhang, K.; Li, Z. In vitro antioxidant activity of acetylated and benzoylated derivatives of polysaccharide extracted from Ulva pertusa (Chlorophyta). Bioorg. Med. Chem. Lett. 2006, 1, 2441-2445. [CrossRef] [PubMed]

21. Pengzhan, Y.; Quanbin, Z.; Ning, L.; Zuhong, X.; Yanmei, W.; Zhien, L. Polysaccharydes from Ulva pertusa (Chlorophyta) and preliminary studies on their antihyperlipidemia activity. J. App. Phycol. 2003, 15, 21-27. [CrossRef] 
22. Pengzhan, Y.; Ning, L.; Xiguang, 1.; Gegei, Z.; Quanbin, Z.; Pengcheng, L. Antihiperlipidemic effects of different molecular weight sulfated polysaccharides from Ulva pertusa (Chlorophyta). Pharmacol. Res. 2003, 48, 543-549. [CrossRef]

23. Freitas, M.B.; Ferreira, L.G.; Hawerroth, C.; Duarte, M.E.; Noseda, M.D.; Stadnik, M.J. Ulvans induce resistance against plant pathogenic fungi independently of their sulfation degree. Carbohydr. Polym. 2015, 133, 384-390. [CrossRef] [PubMed]

24. Pellizzari, F.; Oliveira, M.C.; Medeiros, A.; Yokoya, N.S.; Oliveira, E.C. Morphology, ontogeny, and phylogenetic position of Gayralia brasiliensis sp. nov. (Ulotrichales, Chlorophyta) from the southern coast of Brazil. Bot. Mar. 2013, 56, 197. [CrossRef]

25. Pellizzari, F.; Reis, R.P. Seaweed cultivation on the Southern and Southeastern Brazilian Coast. Braz. J. Pharmacogn. 2011, 21, 305-312. [CrossRef]

26. Cassolato, J.E.F.; Noseda, M.D.; Pujol, C.A.; Pellizzari, F.M.; Damonte, E.B.; Duarte, M.E.R. Chemical structure and antiviral activity of the sulfated heterorhamnan isolated from the green seaweed Gayralia oxysperma. Carbohydr. Res. 2008, 343, 3085-3095. [CrossRef] [PubMed]

27. Ropellato, J.; Carvalho, M.M.; Ferreira, L.G.; Noseda, D.; Zuconellib, A.R.; Gonçalves, D.G.; Ducattia, J.B.R.; Kenskib, N.C.; Nasatoa, S.L.; Winnischoferb, M.B.; et al. Sulfated heterorhamnans from the green seaweed Gayralia oxysperma: Partial depolymerization, chemical structure and antitumor activity. Carbohydr. Polym. 2015, 117, 476-485. [CrossRef] [PubMed]

28. da Silva, A.C.; Ferreira, L.G.; Duarte, M.E.; Noseda, M.D.; Sanchez, E.F.; Fuly, A.L. Sulfated Galactan from Palisada flagellifera Inhibits Toxic Effects of Lachesis muta Snake Venom. Mar. Drugs 2015, 13, 3761-3775. [CrossRef] [PubMed]

29. da Silva, A.C.; Ferreira, L.G.; Duarte, M.E.; Fujii, M.T.; Sanchez, E.F.; Noseda, M.; Fuly, A.L. Protective Effect of the Sulfated Agaran Isolated from the Red Seaweed Laurencia aldingensis Against Toxic Effects of the Venom of the Snake, Lachesis muta. Mar. Biotechnol. 2016, 18, 619-629. [CrossRef] [PubMed]

30. Angulo, Y.; Lomonte, B. Inhibitory effect of fucoidan on the activities of crotaline snake venom myotoxic phospholipases A2. Biochem. Pharmacol. 2003, 66, 1993-2000. [CrossRef]

31. Azofeifa, K.; Angulo, Y.; Lomonte, B. Ability of fucoidan to prevent muscle necrosis induced by snake venom myotoxins: Comparison of high-and low-molecular weight fractions. Toxicon 2008, 51, 373-380. [CrossRef] [PubMed]

32. Gutiérrez, J.M.; Fan, H.W.; Silvera, C.L.; Ângulo, Y. Stability, distribution and use of antivenoms for snakebite envenomation in Latin America: Report of a workshop. Toxicon 2009, 53, 625-630. [CrossRef] [PubMed]

33. Harris, J.B.; Faiz, M.A.; Rahman, M.R.; Jalil, M.M.; Ahsan, M.F.; Theakston, R.D.; Warrell, D.A.; Kuch, U. Developed no signs of systemic envenoming. Trans. R. Soc. Trop. Med. Hyg. 2010, 320-327. [CrossRef] [PubMed]

34. Soares, A.M.; Ticli, F.K.; Marcussi, S.; Lourenço, M.V.; Januário, A.H.; Sampaio, S.V.; Giglio, J.R.; Lomonte, B.; Pereira, O.S. Medicinal plants with inhibitory properties against snake venoms. Curr. Med. Chem. 2005, 12, 2625-2641. [CrossRef] [PubMed]

35. Faulkner, D.J. Marine natural products. Nat. Prod. Rep. 2002, 19, 1-48. [PubMed]

36. da Silva, N.M.; Arruda, E.Z.; Murakami, Y.; Moraes, R.A.; El-Kik, C.Z.; Tomaz, M.A.; Fernandes, F.F.; Oliveira, C.Z.; Soares, A.M.; Giglio, J.R.; et al. Evaluation of three Brazilian antivenom ability to antagonize myonecrosis and hemorrhage induced by Bothrops snake venoms in a mouse model. Toxicon 2007, 50, 196-205. [CrossRef] [PubMed]

37. da Silva, S.L.; Calgarotto, A.K.; Maso, V.; Damico, D.C.; Baldasso, P.; Veber, C.L.; Villar, J.Á.; Oliveira, A.R.; Comar, J.R.; Oliveira, K.M.; et al. Molecular modeling and inhibition of phospholipase $\mathrm{A}_{2}$ by polyhydroxy phenolic compounds. Eur. J. Med. Chem. 2007, 684, 312-321. [CrossRef] [PubMed]

38. Shi, C.S.; Sang, Y.X.; Sun, G.Q.; Li, T.Y.; Gong, Z.S.; Wang, X.H. Characterization and bioactivities of a novel polysaccharide obtained from Gracilariopsis lemaneiformis. Anais da Academia Brasileira de Ciências 2017, 89, 175-189. [CrossRef] [PubMed]

39. Ciancia, M.; Quintana, I.; Cerezo, A.S. Overview of anticoagulant activity of sulfated polysaccharides from seaweeds in relation to their structures, focusing on those of green seaweeds. Curr. Med. Chem. 2010, 17, 2503-2529. [CrossRef] [PubMed] 
40. Vishchuk, O.S.; Ermakova, S.P.; Zvyagintseva, T.N. The effect of sulfated (1 $\rightarrow 3)$-alpha-1-fucan from the brown alga Saccharina cichorioides Miyabe on resveratrol-induced apoptosis in colon carcinoma cells. Mar. Drugs 2013, 11, 194-212. [CrossRef] [PubMed]

41. Fuly, A.L.; de Miranda, A.L.; Zingali, R.B.; Guimarães, J.A. Purification and characterization of a phospholipase $\mathrm{A}_{2}$ isoenzyme isolated from Lachesis muta snake venom. Biochem. Pharmacol. 2002, 63, 1589-1597. [CrossRef]

42. Garcia, E.S.; Guimaraes, J.A.; Prado, J.L. Purification and characterization of a sulfhydryl-dependent protease from Rhodnius prolixus midgut. Arch. Biochem. Biophys. 1978, 188, 315-322. [CrossRef]

43. Kondo, H.; Kondo, S.; Ikezawa, H.; Murata, R. Studies of the quantitative method for determination of hemorrhagic activity of Habu snake venom. J. Med. Sci. Biol. 1960, 13, 43-52. [CrossRef]

44. Yamakawa, M.; Nozani, M.; Hokama, Z. Animal, Plant and Microbial. Toxins 1976, 49, 97-120.

45. Melo, P.A.; Suarez-Kurtz, G. Release of sarcoplasmic enzymes from skeletal muscle by Bothrops jararacussu venom: Antagonism by heparin and by the serum of South American marsupials. Toxicon 1988, 26, 87-95. [CrossRef]

(C) 2018 by the authors. Licensee MDPI, Basel, Switzerland. This article is an open access article distributed under the terms and conditions of the Creative Commons Attribution (CC BY) license (http:// creativecommons.org/licenses/by/4.0/). 